\title{
Correlation Between Glutathione Plasma with Degree Severity of Melasma in Balinese Women
}

This article was published in the following Dove Press journal:

Clinical, Cosmetic and Investigational Dermatology

\author{
Anak Agung Gde Putra \\ Wiraguna \\ Embun Dini Hari \\ I Gusti Ayu Agung Praharsini
}

Dermatology and Venereology Department, Faculty of Medicine, Universitas Udayana-Sanglah General Hospital, Denpasar, Bali, Indonesia
Correspondence: Anak Agung Gde Putra Wiraguna

Dermatology and Venereology

Department, Faculty of Medicine,

Universitas Udayana-Sanglah General

Hospital, Denpasar, Bali, Indonesia

Email wiraguna@unud.ac.id
Introduction: Melasma is a condition of hyperpigmentation of the facial skin that increases in prevalence with ageing. The alleged involvement of reactive oxygen species and antioxidants is the basis of the pathology of melasma. Glutathione is one of the non-enzymatic antioxidants produced by the body and plays a role in melanogenesis. The purpose of this study was to examine serum glutathione levels on the severity of melasma.

Methods: This study used a cross-sectional design conducted at the Cosmetic Dermatology Clinic at Sanglah Hospital, Denpasar, from September to October 2016. Serum glutathione was examined through venous blood with ELISA method, and the severity of melasma was assessed using melasma area severity index (MASI). Independent $t$-test and ANOVA were used to evaluate differences in plasma glutathione levels based on the characteristics of the sample. Pearson correlation test and linear regression were used to assess the relationship between MASI and plasma glutathione.

Results: This study involved 47 people with a clinical diagnosis of melasma. There was a significant strong negative correlation between plasma glutathione and MASI $(\mathrm{p}<0.001 ; \mathrm{r}=$ $-0.624)$. Mild melasma $(1.89 \pm 0.28 \mu \mathrm{mol} / \mathrm{L})$ had higher plasma glutathione levels compared to moderate melasma $(1.53 \pm 0.13 \mu \mathrm{mol} / \mathrm{L})$ and severe $(1.18 \pm 0.20 \mu \mathrm{mol} / \mathrm{L})(\mathrm{p}=0.043)$. Linear regression showed a significant negative linear relationship between MASI scores against plasma glutathione $(\beta=-58.2 ; \mathrm{p}<0.01)$.

Conclusion: Glutathione plasma has a strong negative correlation with the MASI score in person with melasma.

Keywords: melasma, skin, pigmentation, glutathione

\section{Introduction}

The skin is the outermost layer which is the most extensive organ of the human body. The role of the skin as protective of human body from the environment. Healthy skin is essential so that homeostasis can run normally. Skin wellness is very important, not only as an appearance but also to prevent various diseases. ${ }^{1}$ Along with concerns about ageing and acne, uneven pigmentation is one of the most common complaints heard by dermatologists. ${ }^{2}$

Melasma is one of the skin problems that is often found; the emergence of melasma causes disruption to the facial skin as well as causing a decrease in selfconfidence. Melasma is hyper melanosis obtained mainly on the faces of women in reproductive age caused by dysfunction in the process of melanogenesis. ${ }^{3}$ The etiopathogenesis is not yet clear, but is presumably due to genetic, hormonal, ultraviolet light, and drug predisposition. 
Melasma is formed through various oxidative reactions involving the amino acid tyrosinase to form the enzyme tyrosinase. The exact cause of melasma is unknown, but various risk factors have been suggested as triggers of melasma. The risk factors most frequently cited are genetic factors, female sex hormones, oral contraceptives, exposure to ultraviolet (UV) radiation, cosmetics, and drugs. ${ }^{4}$

UV radiation and visible light can cause lipid peroxidase in cellular membranes, causing the formation of free radicals that can stimulate melanogenesis. Although the skin can neutralize these free radicals formed by defending the antioxidant system, continuous and extensive exposure to UV radiation can cause a decrease in the antioxidant capacity of the skin and cause oxidative damage, which in turn causes interference with skin hyperpigmentation. ${ }^{4}$

Melasma is a condition of hyperpigmentation arising from decreased natural antioxidants and increased production of reactive oxygen species (ROS) or free radicals. Antioxidants are substances that can inhibit oxidative damage caused by free radicals. Specifically, antioxidants are enzymes, vitamins, minerals, coenzymes and plants that help our body to prevent and fight damage caused by free radicals and toxins. Glutathione (GSH) is one of the non-enzymatic antioxidants produced by the body. The concentration of these antioxidants in cells is a parameter used to assess the oxidant-antioxidant activity in the pathogenesis of melasma. ${ }^{5,6}$ A previous study by Katiyar et $\mathrm{al}^{4}$ found decreased levels of GSH in person with melasma compared to controls.

There has been no research on the relationship between plasma GSH levels and the severity of melasma. Measurement of the severity of melasma can be done using the Melasma Area and Severity Index (MASI) score. ${ }^{7}$

\section{Methods}

\section{Study Design and Population}

This study used an analytic cross-sectional design, which was conducted at Sanglah General Hospital from September 2016 to October 2016. Samples were obtained through Cosmetic Dermatology Outpatient Clinic. Samples in this study are melasma patients who have not yet received any treatment. ${ }^{8-14}$ The inclusion criteria in this study were melasma patients aged 30-60 years and were willing to participate in the study after obtaining full-informed consent. Exclusion criteria in this study were active smokers, active hormonal therapy, consumption of antioxidants in the past 4 weeks including glutathione, other dermatology diseases such as vitiligo, psoriasis, and another chronic systemic disease (diabetes mellitus, heart failure, systemic lupus, etc.). The sample in this study was 47 people.

\section{Glutathione Assay and Melasma Examination}

Blood samples were taken through a cubital vein, a glutathione examination kit using the QuantiChrom TM Glutathione Assay Kit (Elisa Method). The sample was immediately transferred to the lab. Melasma assessment was performed by one dermatologist on all samples using the criteria for melasma area severity index (MASI).

\section{Statistical Analysis}

Statistical analysis in this study uses SPSS software version 25.0 for Windows (IBM Corporation, Armonk, NY, USA). Independent $t$-test and ANOVA were used to compare serum glutathione values based on sample characteristics. Partial correlation test (controlling for age variable) to assess the correlation of plasma glutathione levels to MASI, multivariable analysis using linear regression (controlling for age variable) to evaluate the relationship of plasma glutathione to MASI by controlling the sample characteristic variables. All values are considered significant if $p<0.05$.

\section{Result}

The study involved 47 people with a clinical diagnosis of melasma. The majority of the sample were women, range 41-50 years old, Fitzpatrick IV skin type, had a family history of melasma, with daily UV exposure 3-6 hrs per day, dentofacial melasma pattern, mixed melasma type, and mild category of melasma based on MASI index (Table 1).

There were no significant differences in GSH levels based on gender, skin type, melasma type, melasma pattern, and daily UV exposure. Significant differences were found in GSH levels based on the severity of melasma, mild melasma tends to have higher GSH compared to moderate and severe melasma $(\mathrm{p}=0.043)$. GSH level has a tendency to decrease with age (Table 2).

There was a significant strong negative correlation between plasma GSH levels and MASI scores $(\mathrm{p}<0.001 ; \mathrm{r}=-0.624)$. This can be interpreted as the lower the GSH plasma the more severe the severity of melasma (Table 2 and Figure 1).

In the linear regression test (Table 3), beta coefficient $(\beta-0.61)$ was obtained, indicating a significant negative effect between the MASI score and plasma GSH levels in the melasma patient. Each increase in the MASI +1 score will be followed by a decrease in GSH level of $0.81 \mu \mathrm{mol} /$ 
Table I Characteristics of the Study

\begin{tabular}{|c|c|c|c|}
\hline Characteristics & $n=47$ & $\begin{array}{l}\text { Plasma GSH } \\
(\mu \mathrm{mol} / \mathrm{L})\end{array}$ & $\mathbf{p}$ \\
\hline $\begin{array}{l}\text { Sex } \\
\qquad \text { Male } \\
\text { Female }\end{array}$ & $\begin{array}{l}5(10.6 \%) \\
42(89.4 \%)\end{array}$ & $\begin{array}{l}1.73 \pm 0.12 \\
1.82 \pm 0.34\end{array}$ & 0.422 \\
\hline $\begin{array}{l}\text { Age } \\
\qquad \begin{array}{l}3 I-40 \text { years } \\
4 I-50 \text { years } \\
5 I-60 \text { years }\end{array}\end{array}$ & $\begin{array}{l}13(27.7 \%) \\
25(53.2 \%) \\
9(19.1 \%)\end{array}$ & $\begin{array}{l}2.03 \pm 0.20 \\
1.74 \pm 0.31 \\
I .71 \pm 0.37\end{array}$ & $0.022^{*}$ \\
\hline $\begin{array}{l}\text { Skin type (Fitzpatrick) } \\
\text { IV } \\
\text { V }\end{array}$ & $\begin{array}{l}26(55.3 \%) \\
21(44.7 \%)\end{array}$ & $\begin{array}{l}1.82 \pm 0.35 \\
1.81 \pm 0.29\end{array}$ & 0.751 \\
\hline $\begin{array}{l}\text { Family history of } \\
\text { melasma } \\
\text { Yes } \\
\text { No }\end{array}$ & $\begin{array}{l}35(74.5 \%) \\
12(25.5 \%)\end{array}$ & $\begin{array}{l}1.79 \pm 0.32 \\
1.86 \pm 0.33\end{array}$ & 0.369 \\
\hline $\begin{array}{l}\text { Daily UV exposure } \\
30 \text { minute-3 hours } \\
3-6 \text { hours } \\
6-9 \text { hours } \\
9-12 \text { hours }\end{array}$ & $\begin{array}{l}13(27.6 \%) \\
2 \mid(44.7 \%) \\
7(14.9 \%) \\
6(12.8 \%)\end{array}$ & $\begin{array}{l}1.94 \pm 0.33 \\
1.81 \pm 0.35 \\
1.72 \pm 0.32 \\
1.68 \pm 0.02\end{array}$ & 0.052 \\
\hline $\begin{array}{l}\text { Melasma pattern } \\
\text { Malar } \\
\text { Dentofacial } \\
\text { Mandibular }\end{array}$ & $\begin{array}{l}8(17 \%) \\
37(87.7 \%) \\
2(4.3 \%)\end{array}$ & $\begin{array}{l}2.03 \pm 0.27 \\
1.77 \pm 0.32 \\
1.81 \pm 0.20\end{array}$ & 0.073 \\
\hline $\begin{array}{l}\text { Type of melasma } \\
\text { Epidermal } \\
\text { Dermal } \\
\text { Mixed }\end{array}$ & $\begin{array}{l}7(14.9 \%) \\
4(8.5 \%) \\
36(76.6 \%)\end{array}$ & $\begin{array}{l}1.88 \pm 0.21 \\
1.93 \pm 0.47 \\
1.79 \pm 0.32\end{array}$ & 0.216 \\
\hline $\begin{array}{l}\text { Severity of melasma } \\
\text { (MASI) } \\
\text { Mild } \\
\text { Moderate } \\
\text { Severe }\end{array}$ & $\begin{array}{l}38(80.85 \%) \\
7(14.89 \%) \\
2(4.25 \%)\end{array}$ & $\begin{array}{l}1.89 \pm 0.28 \\
1.53 \pm 0.13 \\
1.18 \pm 0.20\end{array}$ & $0.043^{*}$ \\
\hline
\end{tabular}

Note: *Significant $(p<0.05)$.

Abbreviations: GSH, glutathione; MASI, melasma area severity index; UV, ultraviolet.

Table 2 Partial Correlation Model Between Plasma Glutathione and MASI Score

\begin{tabular}{|l|l|l|}
\hline Variable & \multicolumn{2}{|l|}{ MASI Score } \\
\hline Glutathione plasma & $\mathrm{r}$ & -0.624 \\
& $\mathrm{P}$ & $<0.00 I^{*}$ \\
& $\mathrm{n}$ & 47 \\
\hline
\end{tabular}

Note: *Significant $(p<0.05)$.

Abbreviation: MASI, melasma area severity index.

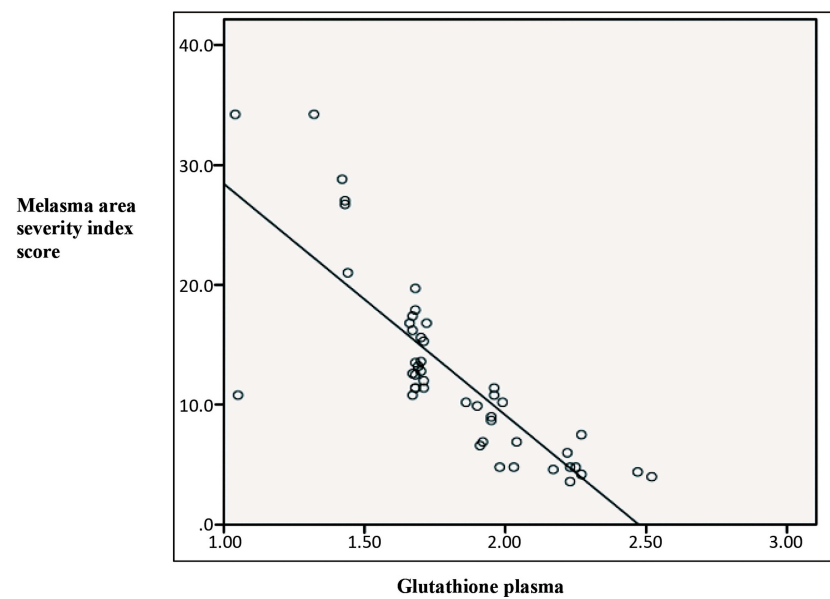

Figure I Scatter plot correlation between melasma area severity index score with glutathione plasma shows a downward line (negative correlation).

Table 3 Linear Regression Analysis on Plasma Glutathione with the Severity of Melasma Based on MASI Score

\begin{tabular}{|l|l|l|l|}
\hline Variable & $\boldsymbol{\beta}$ & $\mathbf{R}^{2}$ & $\mathbf{p}$ \\
\hline GSH & -0.62 & 58.2 & $<0.00 I^{*}$ \\
\hline
\end{tabular}

Note: *Significant $(\mathrm{p}<0.05)$.

Abbreviations: GSH, glutathione; MASl, melasma area severity index.

L. Based on the coefficient of determination $\left(\mathrm{R}^{2}=58.2\right)$ it means $66.1 \%$ the severity of melasma (MASI score) was affected by GSH plasma, and the remaining $41.8 \%$ influenced by another factor.

\section{Discussion}

In this study, there was a strong negative correlation between plasma glutathione levels and the severity of melasma. Glutathione is a compound that is very important in maintaining cell membrane stability; the sulfhydryl group owned by glutathione can reduce the peroxide formed during $\mathrm{O}_{2}$ transfer and protect against free radicals. Cellular glutathione concentration has a significant effect as an antioxidant and varies in amount according to lifestyle and oxidative stress. Under conditions of oxidative stress, glutathione concentration can decrease. ${ }^{6}$ The role of GSH as a skin-lightening agent was accidentally discovered as a side effect in the treatment of chronic diseases using glutathione. Various mechanisms of the impact of glutathione hypopigmentation have been widely discussed, with tyrosinase inhibition being the most 
important mechanism. Tyrosinase can be inhibited directly through copper chelation by the thiol group. The second mechanism of glutathione inhibits the transfer of tyrosinase to premelanosomes which is a place for melanin synthesis. ${ }^{5,7}$

The third mechanism, tyrosinase inhibition indirectly through its antioxidant effect. Glutathione shifts melanogenesis from the synthesis of eumelanin to pheomelanin through the reaction between the thiol and dopaquinone groups causing the formation of sulfhydryl-dopa conjugates. ${ }^{9}$ This composition apparently inhibits tyrosinase. Hyperpigmentation is seen when this sulfhydryl composition is oxidized and inactivated by environmental factors such as heat, radiation, and inflammation due to the loss of the inhibitory effect on tyrosinase. Halprin and Ohkawara et $\mathrm{al}^{10}$ found physical and biochemical evidence of the composition of this sulfhydryl as glutathione.

There are no other studies comparing plasma GSH levels with the severity of melasma. However, the results of this study are similar to other studies that prove the role of oxidative stress in the pathogenesis of melasma. According to Shuja et $\mathrm{al}^{11}$ in his study, plasma GSH levels in melasma patients decreased significantly compared to controls and are thought to be a risk factor in the severity of melasma. Katiyar et $\mathrm{al}^{6}$ also found a significant decrease in GSH levels $(\mathrm{p}<0.05)$ in melasma subjects compared to controls. Other studies that support a reduction in GSH levels in melasma subjects compared to controls are studies conducted by Jing et $\mathrm{al}^{12}$ and also by Hamadi et al. ${ }^{13}$

GSH exerts antioxidant properties to convert hydrogen peroxide into oxygen and water, thereby eliminating the effects of oxidative stress in the skin tissue. Higher melasma area severity index may represent higher oxidative stress, the higher oxidative stress condition, and certainly requires more GSH to cope with free radicals, this may be the basis for the finding of lower melasma levels often with the increasing severity of melasma in this study. ${ }^{14}$

In the linear regression test (Table 3), beta coefficient ( $\beta=-0.62$ ) was obtained, indicating a strong significant negative effect between MASI score and plasma GSH levels in the Melasma Subject. Each increase in the MASI +1 score will be followed by a decrease in GSH level of $0.81 \mu \mathrm{mol} / \mathrm{L}$. Based on the coefficient of determination $\left(\mathrm{R}^{2}=58.2\right)$ it means that $66.1 \%$ of the severity of melasma is influenced by plasma GSH levels, the remaining $33.9 \%$ is influenced by other factors. The influence of other factors may originate from genetic, environmental, hormonal, antioxidant levels other than GSH. According to Shuja et $\mathrm{a}^{11}$ study, risk factors for melasma other than GSH, there was also a decrease in levels of other antioxidants such as superoxide dismutase (SOD), catalase, vitamin $\mathrm{E}$, and vitamin $\mathrm{C}$ which were statistically significant in melasma subjects compared to controls. Katiyar et $\mathrm{al}^{6}$ in his study also found a significant increase in estrogen and progesterone levels in melasma subjects compared to controls. In this study oxidative stress parameters other than GSH such as SOD and catalase were found to be decreased, whereas glutathione peroxidase (GSH-px), tyrosine hydroxylase (TH), and malondialdehyde (MDA) were increased in melasma subjects compared to controls.

The limitation in this study is that GSH measurements are carried out through venous blood samples not through skin biopsy in melasma, because they are invasive. Aside from that, in this study, no control group was used, so the normal value of blood GSH is still unknown. Besides that, we have not been able to find any up- and down-regulation of GSH in melasma.

\section{Conclusion}

Glutathione plasma has a strong negative correlation with the MASI score in melasma subjects as evidenced by the lower plasma glutathione levels, the MASI score (the severity of melasma) will be higher.

\section{Ethical Aspect}

All study protocols had been approved by the Ethical Committee Faculty of Medicine/Sanglah General Hospital, Bali-Indonesia with ethical clearance reference number 1874/UN.14.2/Litbang/2016. All patients had written signed informed consent prior to any data collection. All study procedure was conducted in accordance with the declaration of Helsinki.

\section{Disclosure}

The authors declare there are no conflicts of interest regarding the publication of the current study.

\section{References}

1. Darlenski R, Kazandjieva J, Tsankov N. Skin barrier function: morphological basis and regulatory mechanism. J Clin Med. 2011;4 (1):36-45.

2. Paek SY, Pandya AG. Disorders of hyperpigmentation. In: Skin of Color. New York: Springer; 2013:139-160.

3. Handel AC, Lima PB, Tonolli VM, Miot LD, Miot HA. Risk factors for facial melasma in women: a case-control study. $\mathrm{Br} J$ Dermatol. 2014;171(3):588-594. doi:10.1111/bjd.13059

4. Seckin HY, Kalkan GB, Akbas A, Onder Y, Ozyurt H, Sahin M. Oxidative stress status in patient with melasma. Cutan Ocul Toxicol. 2014;33(3):212-217. doi:10.3109/15569527.2013.834496 
5. Arjinpathana N, Asawanonda P. Glutathione as an oral whitening agent: a randomized, double-blind, placebo-controlled study. J Dermatolog Treat. 2012;23(2):97-102. doi:10.3109/09546631003801619

6. Katiyar S. Studies of the Therapeutic Efficacy of Combination Therapy in Melasma Patients with Specific Reference to Its Antioxidant Properties. Department of Biochemistry. India: Gajra Raja Medical College; 2014:121-138.

7. Kimborough CK, Griffiths CE, Finkel LJ, Hamilton TA, Bulengo SM, Ellis CN. Topical retinoic acid for melasma in black patients: a vehicle controlled clinical trial. Arch Dermatol. 1994;130 (6):727-733. doi:10.1001/archderm.1994.01690060057005

8. Hari ED Negative correlation between degree severity of melasma and glutathione [Thesis]. Universitas Udayana. 2016; Available at: https://e-perpus.unud.ac.id/repositori/tesis?nim=1214088101.

9. Sonthalia S, Sarkar R. Etiopathogenesis of melasma. Pigment Int. 2015;2(1):21-27. doi:10.4103/2349-5847.159389
10. Halprin KM, Ohkawara A. Glutathione and human pigmentation. Arch Dermatol. 1996;94(3):355-357. doi:10.1001/archderm.19 66.01600270105022

11. Shuja N, Bajwa UM, Iqbal S, et al. Assessment of circulating biochemical markers and antioxidative status in patients suffering from melasma. PJMHS. 2015;9(1):275-277.

12. Jing Z, Qilian Z, Haiquan W. A study on the mechanism of catechins for melasma. Chin J Med Asthet Cosmet. 1998;4:13-19.

13. Hamadi SA, Mohammed MM, Aljaf AN, Abdulrazak A. The role of topical and oral melatonin in management of melasma patients. J Arab Univ Basic Appl Sci. 2009;8:30-42.

14. Lushcak VI. Glutathione homeostasis and functions: potential target for medical interventions. J Amino Acids. 2012;2012:1-26. doi:10.1155/2012/ 736837

Clinical, Cosmetic and Investigational Dermatology

\section{Publish your work in this journal}

Clinical, Cosmetic and Investigational Dermatology is an international, peer-reviewed, open access, online journal that focuses on the latest clinical and experimental research in all aspects of skin disease and cosmetic interventions. This journal is indexed on CAS
The manuscript management system is completely online and includes a very quick and fair peer-review system, which is all easy to use. Visit http://www.dovepress.com/testimonials.php to read real quotes from published authors. 